\title{
Pregnancy-Associated Breast Cancer - Special Features in Diagnosis and Treatment
}

\author{
Wolfgang Janni ${ }^{a}$ Brigitte Rack ${ }^{a}$ Bernd Gerber ${ }^{b}$ Ingo Bauerfeind ${ }^{c}$ Anette Krause ${ }^{a}$ Darius Dian ${ }^{a}$ \\ Harald Sommer $^{\mathrm{a}}$ Klaus Friese ${ }^{\mathrm{a}}$ \\ a Obstetrics and Gynecology Clinic and Polyclinic of Ludwig Maximilian University, Klinikum Innenstadt, München, \\ bUniversity Gynecology Clinic, Rostock University, \\ c Obstetrics and Gynecology Clinic and Polyclinic of Ludwig Maximilian University, Klinikum Großhadern, München, Germany
}

\section{Key Words}

Breast cancer · Pregnancy · Overall survival .

Distant metastasis · Relapse · Prognosis · Chemotherapy · Endocrine treatment

\section{Summary}

For obvious psychological reasons it is difficult to associate pregnancy - a life-giving period of our existence with life-threatening malignancies. Symptoms pointing to malignancy are often ignored by both patients and physicians, and this, together with the greater difficulty of diagnostic imaging, probably results in the proven delay in the detection of breast cancers during pregnancy. The diagnosis and treatment of breast cancer are becoming more and more important, as the fulfillment of the desire to have children is increasingly postponed until a later age associated with a higher risk of carcinoma, and improved cure rates of solid tumors no longer exclude subsequent pregnancies. The following article summarizes the special features of the diagnosis and primary therapy of pregnancy-associated breast cancer with particular consideration of cytostatic therapy.

\section{Introduction}

For obvious psychological reasons it is difficult to associate pregnancy - a life-giving period of our existence - with lifethreatening malignancies. Symptoms pointing to malignancy are often ignored by both patients and physicians, and this, to-

\author{
Schlüsselwörter \\ Mammakarzinom - Schwangerschaft · Gesamtüberleben · \\ Fernmetastasen · Rezidiv · Prognose · Chemotherapie · \\ Endokrine Therapie
}

\section{Zusammenfassung}

Schwangerschaft als lebensspendende Phase unseres Daseins und lebensbedrohende Malignome sind schon aus naheliegenden psychologischen Gründen nur schwer miteinander in Zusammenhang zu bringen. Symptome, die auf ein Malignom hindeuten, werden nicht selten von Patientin und Arzt ignoriert, woraus neben der erschwerten bildgebenden Diagnostik vermutlich die nachweisliche Verzögerung im Nachweis von Mammakarzinomen während der Schwangerschaft resultiert. Die Diagnostik und Therapie des Mammkarzinoms gewinnt zunehmend an Bedeutung, da die späte Realisierung des Kinderwunschs die Schwangerschaft zunehmend in ein Lebensalter mit höherem Karzinomrisiko rückt und höhere Heilungsraten von soliden Tumoren eine nachfolgende Schwangerschaft nicht mehr grundsätzlich ausschließen. Der folgende Artikel fasst die Besonderheiten von Diagnostik und Primärtherapie des schwangerschaftsassoziierten Mammakarzinoms unter besonderer Berücksichtigung der zytostatischen Therapie zusammen.

gether with the greater difficulty of diagnostic imaging, probably results in the proven delay in the detection of breast cancers during pregnancy [1-4]. The diagnosis and treatment of breast cancer are becoming more and more important, as the fulfillment of the desire to have children is increasingly postponed until a later age associated with a higher risk of carci-

\begin{tabular}{|c|c|}
\hline KARGER & (C) 2006 S. Karger GmbH, Freiburg \\
\hline $\begin{array}{l}\text { Fax +497614520714 } \\
\text { E-mail Information@Karger.de } \\
\text { www.karger.com }\end{array}$ & $\begin{array}{l}\text { Accessible online at: } \\
\text { www.karger.com/onk }\end{array}$ \\
\hline
\end{tabular}


noma, and improved cure rates of solid tumors no longer exclude subsequent pregnancies [5-9]. Various ethical aspects considering potential conflicts between optimizing maternal prognosis and prolonging pregnancy will have to become part of an informed consent between physicians and patients. This dialogue, however, has to be based on the profound knowledge of the state of the art in the treatment of pregnancyassociated breast cancer. The following article summarizes the special features of the diagnosis and primary therapy of pregnancy-associated breast cancer with particular consideration of cytostatic therapy.

\section{Epidemiology and Prognosis}

Pregnancy-associated breast cancer is defined as breast cancer occurring during pregnancy or up to 1 year postpartum [10]. The incidence is increasing particularly in women having children in the last third of the fertile period of their lives. With an incidence of 1 in 3,000 to 1 in 10,000 pregnancies, pregnancy-associated breast cancer is the most common solid tumor during pregnancy after cervical carcinoma [11, 12].

The prognosis of pregnancy-associated breast cancer is identical with that of similar tumor stages outside of pregnancy, with an overall survival rate of $57 \% 5$ years after the initial diagnosis [13]. However, pregnancy-associated breast cancer is often diagnosed in the more advanced stages of the disease, which might be due to delayed discovery as well as a more aggressive tumor biology.

\section{Diagnosis}

Making the diagnosis is rendered more difficult by the changed consistency and increased weight of the breast during pregnancy and lactation. Pregnancy delays the diagnosis of breast cancer by an average of 2-6 months [1-4]. A Norwegian study calculated that the diagnosis was delayed by 2.5 months during pregnancy and 6 months during the lactation period [4]. In a similar study by the M.D. Anderson Cancer Center, an average tumor size of pregnancy-associated breast cancer of $3.5 \mathrm{~cm}$ at the time of diagnosis was observed [10]. While mammography during pregnancy can be classified as a safe procedure with regard to the fetal radiation load of approximately 0.004 Gy [14], it often leads to false-negative results due to the altered radiodensity of the breast [2,3]. Mammography plays a special role in imaging of undefined palpable lesions during pregnancy and lactation, but must be treated with particular care. For this reason, ultrasound examination of the breast is the method of choice for clarifying palpable abnormalities. It is capable of distinguishing between solid and cystic lesions with $97 \%$ certainty $[2,3]$. In a Japanese study, ultrasound examination of the breast showed a sensitivity of $93 \%(n=42)$ [2]. Magnetic resonance imaging is recom- mended only in exceptional cases because of the transplacental action of the contrast agent, the potential heating of the fetus and the increased hypervascularity in pregnancy and lactation which limits the diagnostic value [14]. Screening for metastases with an increased radiation load (e.g. computed tomography, isotope bone scan) should be reserved for situations in which direct therapeutic consequences are derived from these investigations [15].

The diagnosis should be made primarily by punch biopsy for reasons that generally apply to breast cancer [16-18]. The risk of so-called 'milk fistulas' is generally low so that weaning is not obligatory. Due to the hypervascularity during and after pregnancy, the use of compression dressings to prevent hematomas is recommended [10]. The pathologist should always be informed of the patient's gravid status in order to avoid incorrect diagnosis due to pregnancy-associated tissue changes.

\section{Histopathological Features}

The great majority of pregnancy-associated breast cancers (75-90\%) are of the invasive ductal type $[1,2,19]$. The tumor extent is in every respect more advanced than outside of pregnancy. Pregnancy-associated breast cancer is connected with generally bigger tumors and more frequent axillary lymph node metastases and distant metastases. Also, hemangiosis carcinomatosa is observed more often at presentation [2, 19-22]. Views differ on whether this phenomenon is a result of the delayed diagnosis or whether the disease dynamics are accelerated by pregnancy-associated factors such as altered vascularity, higher serum hormone levels or pregnancy-associated immunosuppression. Furthermore, the estrogen receptor status of pregnancy-associated breast cancer patients is negative much more often than that of age-matched control groups, which may be caused by down-regulation of the hormone receptor [1, 2, 13, 22-27]. More recent investigations have also shown that HER2/neu overexpression is encountered more often in pregnancy-associated breast cancer $(58 \%$ of cases) [26].

\section{Surgery and Radiotherapy}

In principle, the locoregional therapy of pregnancy-associated breast cancer is in accordance with the general guidelines for breast cancer therapy. Since there are no conclusive data on primary systemic therapy in pregnant patients, surgery is the primary treatment in most cases. Exceptions in the pregnant situation also include inflammatory or locally advanced carcinomas where primary surgery is not appropriate. The risk of abortion due to surgery involving general anesthesia is slightly increased (rate ratio 1.6-2). Breast-preserving surgery should be attempted and is associated with results similar to 
those obtained with mastectomy [28, 29]. Because of the high incidence of axillary lymph node metastases (56-83\%) [21], systematic axillary dissection is regarded as the gold standard. In recently published studies, measurements of activity after radionuclide labeling in the region of the breast and axilla yielded undetectable or very low radioactivity in the pelvis so that it appears unlikely that the fetus is at risk after sentinel node biopsy. However, because of the absence of clinical data, sentinel lymph node excision with radiotracer labeling should only be performed when strictly indicated [30,31].

Radiation of the breast and/or chest wall is usually not performed during pregnancy because of the risk of malformation and radiotherapy-associated malignancies of the fetus. The risk increase of fetal malignancy is 6.57 cases $/ 10,000 / \mathrm{rad} / \mathrm{y}$ [32]. Since due to the usually advanced tumor stage, the risk of systemic recurrence predominates in the majority of patients, local radiotherapy is in most cases given only after the conclusion of systemic therapy and hence after the pregnancy. Lactation may be impaired after radiation of the breast [23].

\section{Cytostatic Therapy}

Chemotherapy is indicated in the majority of patients with pregnancy-associated breast cancer. After the first trimester, anthracycline-containing chemotherapy is regarded as the treatment standard just as in non-pregnancy-associated breast cancer. In the only prospective study to be carried out on the use of FAC chemotherapy (5-fluorouracil, doxorubicin, cyclophosphamide) during pregnancy, no fetal anomalies were observed [23]. In general, in breast cancer treatment, anthracyclines are regarded as the drugs with the best benefit-risk relationship, while folate antagonists, such as methotrexate, are strictly contraindicated, as they are the main cause of fetal malformation [33]. The systemic use of cytostatic substances during pregnancy must be indicated particularly strictly, as it not only poses risks for the mother but also substantial hazards for the fetus. In principle, the benefits of chemotherapy during pregnancy for the mother must always be weighed against the resulting risks for the fetus, and this situation must be taken into account in the selection, dosage, number of cycles and administration of cytostatic agents [34].

Undoubtedly, the risk for the fetus is highest when chemotherapy is given during the first trimester of pregnancy - the period of gestation in which the dynamics of organogenesis make the embryonic organism particularly vulnerable to cytostatic substances. There is a significantly increased risk of abortion and fetal anomalies, which appears to be greatest between weeks 2 and 8 post-conception [35-37]. In a study by the National Cancer Institute (NCI), all but 2 of 52 chemotherapy-associated fetal anomalies had occurred following chemotherapy during the first trimester. As the risk of fetal malformation is $16 \%$ in the first trimester compared to $1.3 \%$ in the later stages of pregnancy [38], cytostatic therapy should in principle be avoided during this time. After organogenesis is concluded, the hematopoietic system, the central nervous system, the eyes and the ears remain more at risk than other fetal organs [39]. Although the risk of malformation rapidly decreases in the second and third trimester, the risk of intrauterine growth retardation and premature delivery due to cytostatic treatment is increased [40]. However, observational studies have not found any learning disorders or hematological or immunological abnormalities in children up to early school age [41].

Anthracyclines exert their effect by incorporating the highmolecular-weight substance into the DNA. Most data during pregnancy have been obtained with doxorubicin. Fetal malformation occurred in more than 200 patients, but only when the cytostatic drug was used during the first trimester as opposed to later gestational periods [42-47]. As experiences with the use of epirubicin in pregnancy are much more limited ( $n=13$ ) [48, 49], doxorubicin should be the drug of choice, if an efficacy similar to that of epirubicin can be assumed, as is the case with breast cancer. However, the question remains whether fetal cardiotoxicity is a result of the transplacental action of the anthracyclines, which is observed dose-dependently in adults. In an echocardiographic study of fetuses between weeks 20 and 40 of pregnancy, no increase in cardiomyopathy was found when anthracycline-unloaded fetuses were compared to chemotherapy-loaded fetuses [50]. Because of the lack of long-term experience with this substance group, however, appropriate caution is required when considering the indication, as 4 cases of postnatally diagnosed cardiotoxicity have been reported after intrauterine anthracycline loading. Therefore, signs of postnatal heart failure should be particularly watched out for [51, 52].

Antimetabolites, such as the folate antagonist methotrexate, represent the most problematic group of cytostatics with regard to their use in pregnancy. They inhibit the cell metabolism by being incorporated as false substrates during DNA or RNA synthesis regardless of the cell cycle. Methotrexate in a dose of more than $10 \mathrm{mg} /$ week causes malformations in the first trimester similar to those of the aminopterin syndrome: cranial dysostosis, disorders of bone maturation, hypertelorism, broad nasal saddle, micrognathia and ear deformities. Following administration of the antimetabolite 5-fluorouracil during pregnancy, a total of 53 cases were described with different outcome, ranging from unremarkable courses to intrauterine fetal death. Intrauterine growth retardation was observed in $11 \%$ of cases $[53,54]$. The antimetabolites cytarabine and mercaptopurine are not used in gynecological oncology.

Alkylating agents, in particular cyclophosphamide, are also an integral part of common chemotherapy schedules for the treatment of breast cancer. A range of malformations, such as limb, eye and ear deformities, have been observed following the use of cyclophosphamide during the first trimester [55-57]. From the second trimester, alkylating agents can apparently be used with much lower risks. Of 92 documented 
Table 1. Valid chemotherapy regimens in pregnancy-associated breast cancer

\begin{tabular}{lll}
\hline Regimen & Agents & Dosage/administration/interval \\
\hline 4x EC & $\begin{array}{l}\text { epirubicin } \\
\text { cyclophosphamide }\end{array}$ & $90 \mathrm{mg} / \mathrm{m}^{2} /$ i.v. / d1, q3w, 4 cycles \\
& $600 \mathrm{mg} / \mathrm{m}^{2} /$ i.v. / d1, q3w, 4 cycles \\
FEC120 (Levine) & 5-fluorouracil & $500 \mathrm{mg} / \mathrm{m}^{2} /$ i.v. / d1+8, q4w, 6 cycles \\
& $\begin{array}{l}\text { epirubicin } \\
\text { cyclophosphamide }\end{array}$ & $60 \mathrm{mg} / \mathrm{m}^{2} /$ i.v. / d1+8, q4w, 6 cycles \\
FEC100 (Bonneterre) & 5-fluorouracil & $500 \mathrm{mg} / \mathrm{m}^{2} /$ i.v. / d1, q3w \\
& $\begin{array}{l}\text { epirubicin } \\
\text { cyclophosphamide }\end{array}$ & $500 \mathrm{mg} / \mathrm{m}^{2} /$ i.v. / d1, q3w \\
& & \\
\hline
\end{tabular}

q3w: 3-weekly, q4w: 4-weekly, d: day. cases, 2 fetuses died intrauterinely, in each case when the alkylating agent was combined with other cytostatics [58]. Intrauterine growth retardation was observed in $7 \%$ of cases [59]. The alkylating agents dacarbazine and busulfan are not used in gynecological oncology, and there are no conclusive results regarding ifosfamide. Chemotherapy regimens which have been extensively evaluated and have shown acceptable safety are summarized in table 1 .

No or little data is available on newer agents which have proven increased efficacy in the treatment of breast cancer, such as paclitaxel, docetaxel, gemcitabine or capecitabine. Despite the vast experience with taxanes of almost 10 years, only 2 case reports are currently available on the use of taxanes in pregnant patients [60-62]. Considering the modest overall survival benefit of the novel agents in comparison to conventional chemotherapy, such as FEC (5-fluorouracil, epirubicin, cyclophosphamide), the authors recommend favoring cytostatic regimes which have been extensively evaluated.

The timing of chemotherapy during pregnancy should in principle be aimed at completing the final cycle at least 2-4 weeks before the (planned) birth, as both the maternal and the fetal chemotherapy-induced side effects can lead to a significant increase in intra- and postpartum complications. At the time of birth, myelosuppression in the mother should have passed the leukocyte nadir in order to minimize the risk of peripartum infection. Moreover, the organs of the neonate are not capable of sufficiently metabolizing cytostatics still present in the fetal body without the transplacental detoxification assistance of the mother [23, 63, 64].

\section{Endocrine Therapy}

Adjuvant endocrine therapy with anti-estrogens during pregnancy is contraindicated for 2 reasons: on the one hand, a range of tamoxifen-associated fetal anomalies are found in the literature $[65,66]$, and on the other hand, there is currently no evidence that endocrine therapy during pregnancy leads to an improved prognosis. This observation might be attributable to the fact that most pregnancy-associated breast cancers are hormone receptor-negative. Analogously, iatrogenic induction of menopause does not lead to an improved prognosis. In fact, in 2 studies, a worsening of the prognosis was observed in patients who had undergone oophorectomy $[2,20]$. Termination of pregnancy does not lead to an improved prognosis either but may actually impair the prognosis, and it is not indicated from an oncological point of view [12, 67].

\section{Further Family Planning}

Premenopausal breast cancer patients who want to have children frequently seek advice on further family planning after successful conclusion of the primary breast cancer treatment. Unfortunately, all available recommendations are without adequate evidence $[10,68]$. So far, the originally anticipated increase in the risk of recurrence due to the endocrine changes during pregnancy has not been confirmed by any study [69]. However, the survival advantage postulated in a few studies of patients who became pregnant in the years following successful treatment of breast cancer is presumably based on a 'healthy mother effect' $[10,70]$. Despite this fact, there is not data indicating that pregnancy after successful treatment of primary breast cancer compromises maternal prognosis. Consequently, fertility-preserving aspects should be considered when treatment is planned in premenopausal women. Gonadotropin-releasing hormone analogues are the only available medical protection against gonadotoxic chemotherapy. Assisted reproductive technology offers excellent results but requires a delay in implementing chemotherapy. Despite recent reports of embryo development after the transplantation of cryopreserved-thawed ovarian tissue, clinical experience is limited, and the technique remains experimental [71]. In summary, the decision for or against having children after the conclusion of primary breast cancer treatment should be guided by personal lifestyle choices rather than vague medical hypotheses [72]. 


\section{References}

1 Bonnier P, Romain S, Dilhuydy JM, Bonichon F, Julien JP, Charpin C, Lejeune C, Martin PM, Piana $\mathrm{L}$ : Influence of pregnancy on the outcome of breast cancer: a case-control study. Societe Francaise de Senologie et de Pathologie Mammaire Study Group. Int J Cancer 1997;72:720-727.

2 Ishida T, Yokoe T, Kasumi F, Sakamoto G, Makita M, Tominaga T, Simozuma K, Enomoto K, Fujiwara K, Nanasawa T: Clinicopathologic characteristics and prognosis of breast cancer patients associated with pregnancy and lactation: analysis of case-control study in Japan. Jpn J Cancer Res 1992;83:1143-1149.

3 Liberman L, Giess CS, Dershaw DD, Deutch BM, Petrek JA: Imaging of pregnancy-associated breast cancer. Radiology 1994;191:245-248.

4 Tretli S, Kvalheim G, Thoresen S, Host H: Survival of breast cancer patients diagnosed during pregnancy or lactation. Br J Cancer 1988;58:382-384.

5 Abstracts of the 24th Annual Meeting of the German Society of Senology. 2-4 September 2004, Freiburg, Germany. Onkologie 2004;27(suppl 2): $1-65$.

6 Thurlimann B, Muller A, Senn HJ: Management of primary breast cancer: an update. Onkologie 2004; 27:175-179.

7 Harbeck N: Adjuvant chemotherapy in primary breast cancer. Onkologie 2003;26(suppl 7):17-20.

8 Janicke F: Perspectives in oncology. Onkologie 2003;26(suppl 7):3.

9 Abstracts of the 23rd Annual Meeting of the German Society of Senology. 19-21 June 2003, Munich, Germany. Onkologie 2003;26(suppl 2):1-100.

10 Petrek J, Seltzer V: Breast cancer in pregnant and postpartum women. J Obstet Gynaecol Can 2003; 25:944-950.

11 Antonelli NM, Dotters DJ, Katz VL, Kuller JA: Cancer in pregnancy: a review of the literature. Part I. Obstet Gynecol Surv 1996;51:125-134.

12 Woo JC, Yu T, Hurd TC: Breast cancer in pregnancy: a literature review. Arch Surg 2003;138:91-98.

13 Nugent P, O'Connell TX: Breast cancer and pregnancy. Arch Surg 1985;120:1221-1224.

14 Nicklas AH, Baker ME: Imaging strategies in the pregnant cancer patient. Semin Oncol 2000;27:623632

15 Gerber B, Seitz E, Muller H, Krause A, Reimer T, Kundt G, Friese K: Perioperative screening for metastatic disease is not indicated in patients with primary breast cancer and no clinical signs of tumor spread. Breast Cancer Res Treat 2003;82:2937.

16 Poniecka AW, Krasuski P, Gal E, Lubin J, Howard L, Poppiti RJ: Granulomatous inflammation of the breast in a pregnant woman: report of a case with fine needle aspiration diagnosis. Acta Cytol 2001; 45:797-801.

17 Shannon J, Douglas-Jones AG, Dallimore NS: Conversion to core biopsy in preoperative diagnosis of breast lesions: is it justified by results? J Clin Pathol 2001;54:762-765.

18 Westenend PJ, Sever AR, Beekman-De Volder HJ, Liem SJ: A comparison of aspiration cytology and core needle biopsy in the evaluation of breast lesions. Cancer 2001;93:146-150.

19 Petrek JA, Dukoff R, Rogatko A: Prognosis of pregnancy-associated breast cancer. Cancer 1991; 67:869-872.

20 Bunker M, Peters MV: Breast cancer associated with pregnancy or lactation. Am J Obstet Gynecol 1963;85:312-321.
21 Guinee VF, Olsson H, Moller T, Hess KR, Taylor SH, Fahey T, Gladikov JV, van den Blink JW, Bonichon F, Dische S: Effect of pregnancy on prognosis for young women with breast cancer. Lancet 1994;343:1587-1589.

22 Max MH, Klamer TW: Pregnancy and breast cancer. South Med J 1983;76:1088-1090.

23 Berry DL, Theriault RL, Holmes FA, Parisi VM, Booser DJ, Singletary SE, Buzdar AU, Hortobagyi GN: Management of breast cancer during pregnancy using a standardized protocol. J Clin Oncol 1999;17:855-861.

24 Mitre BK, Kanbour AI, Mauser N: Fine needle aspiration biopsy of breast carcinoma in pregnancy and lactation. Acta Cytol 1997;41:1121-1130.

25 Giacalone PL, Laffargue F, Benos P: Chemotherapy for breast carcinoma during pregnancy: A French national survey. Cancer 1999;86:2266-2272.

26 Elledge RM, Ciocca DR, Langone G, McGuire WL: Estrogen receptor, progesterone receptor, and HER-2/neu protein in breast cancers from pregnant patients. Cancer 1993;71:2499-2506.

27 Holdaway IM, Mason BH, Kay RG: Steroid hormone receptors in breast tumours presenting during pregnancy or lactation. J Surg Oncol 1984;25: 38-41.

28 Gwyn K, Theriault R: Breast cancer during pregnancy. Oncology (Huntingt) 2001;15:39-46.

29 Kuerer HM, Cunningham JD, Brower ST, Tartter PI: Breast carcinoma associated with pregnancy and lactation. Surg Oncol 1997;6:93-98.

30 Gentilini O, Cremonesi M, Trifiro G, Ferrari M, Baio SM, Caracciolo M, Rossi A, Smeets A, Galimberti V, Luini A, Tosi G, Paganelli G: Safety of sentinel node biopsy in pregnant patients with breast cancer. Ann Oncol 2004;15:1348-1351.

31 Keleher A, Wendt R 3rd, Delpassand E, Stachowiak AM, Kuerer HM: The safety of lymphatic mapping in pregnant breast cancer patients using Tc-99m sulfur colloid. Breast J 2004;10:492-495.

32 Greskovich JF Jr, Macklis RM: Radiation therapy in pregnancy: risk calculation and risk minimization. Semin Oncol 2000;27:633-645.

33 Ebert U, Loffler H, Kirch W: Cytotoxic therapy and pregnancy. Pharmacol Ther 1997;74:207-220.

34 Cardonick E, Iacobucci A: Use of chemotherapy during human pregnancy. Lancet Oncol 2004;5: 283-291.

35 Caligiuri MA, Mayer RJ: Pregnancy and leukemia. Semin Oncol 1989;16:388-396.

36 Doll DC, Ringenberg QS, Yarbro JW: Antineoplastic agents and pregnancy. Semin Oncol 1989;16: 337-346.

37 Zemlickis D, Lishner M, Degendorfer P, Panzarella T, Sutcliffe SB, Koren G: Fetal outcome after in utero exposure to cancer chemotherapy. Arch Intern Med 1992;152:573-576.

38 Zemlickis D, Lishner M, Degendorfer P, Panzarella T, Burke B, Sutcliffe SB, Koren G: Maternal and fetal outcome after breast cancer in pregnancy. Am J Obstet Gynecol 1992;166:781-787.

39 Williams SF, Bitran JD: Cancer and pregnancy. Clin Perinatol 1985;12:609-623.

40 Zemlickis D, Lishner M, Degendorfer P, Panzarella T, Sutcliffe SB, Koren G: Fetal outcome after in utero exposure to cancer chemotherapy. Arch Intern Med 1992;152:573-576.

41 Aviles A, Niz J: Long-term follow-up of children born to mothers with acute leukemia during pregnancy. Med Pediatr Oncol 1988;16:3-6.

42 Ebert U, Loffler H, Kirch W: Cytotoxic therapy and pregnancy. Pharmacol Ther 1997;74:207-220.
43 Karp GI, von Oeyen P, Valone F, Khetarpal VK, Israel M, Mayer RJ, Frigoletto FD, Garnick MB: Doxorubicin in pregnancy: possible transplacental passage. Cancer Treat Rep 1983;67:773-777.

44 Murray CL, Reichert JA, Anderson J, Twiggs LB: Multimodal cancer therapy for breast cancer in the first trimester of pregnancy. A case report. JAMA 1984;252:2607-2608.

45 Toledo TM, Harper RC, Moser RH: Fetal effects during cyclophosphamide and irradiation therapy. Ann Intern Med 1971;74:87-91.

46 Turchi JJ, Villasis C: Anthracyclines in the treatment of malignancy in pregnancy. Cancer 1988;61: 435-440.

47 Zemlickis D, Lishner M, Degendorfer P, Panzarella T, Sutcliffe SB, Koren G: Fetal outcome after in utero exposure to cancer chemotherapy. Arch Intern Med 1992;152:573-576.

48 Giacalone PL, Laffargue F, Benos P: Chemotherapy for breast carcinoma during pregnancy: A French national survey. Cancer 1999;86:2266-2272.

49 Peres RM, Sanseverino MT, Guimaraes JL, Coser V, Giuliani L, Moreira RK, Ornsten T, SchulerFaccini L: Assessment of fetal risk associated with exposure to cancer chemotherapy during pregnancy: a multicenter study. Braz J Med Biol Res 2001;34:1551-1559.

50 Meyer-Wittkopf M, Barth H, Emons G, Schmidt S: Fetal cardiac effects of doxorubicin therapy for carcinoma of the breast during pregnancy: case report and review of the literature. Ultrasound Obstet Gynecol 2001;18:62-66.

51 Cardonick E, Iacobucci A: Use of chemotherapy during human pregnancy. Lancet Oncol 2004;5: 283-291.

52 Toledo TM, Harper RC, Moser RH: Fetal effects during cyclophosphamide and irradiation therapy. Ann Intern Med 1971;74:87-91.

53 Cardonick E, Iacobucci A: Use of chemotherapy during human pregnancy. Lancet Oncol 2004;5: 283-291.

54 Peres RM, Sanseverino MT, Guimaraes JL, Coser V, Giuliani L, Moreira RK, Ornsten T, SchulerFaccini L: Assessment of fetal risk associated with exposure to cancer chemotherapy during pregnancy: a multicenter study. Braz J Med Biol Res 2001;34:1551-1559.

55 Doll DC, Ringenberg QS, Yarbro JW: Antineoplastic agents and pregnancy. Semin Oncol 1989;16: 337-346.

56 Reynoso EE, Keating A, Baker MA: Acute leukemia occurring 19 years after treatment of acute lymphoblastic leukemia. Cancer 1987;59: 1963-1965.

57 Toledo TM, Harper RC, Moser RH: Fetal effects during cyclophosphamide and irradiation therapy. Ann Intern Med 1971;74:87-91.

58 Cantini E, Yanes B: Acute myelogenous leukemia in pregnancy. South Med J 1984;77:1050-1052

59 Cardonick E, Iacobucci A: Use of chemotherapy during human pregnancy. Lancet Oncol 2004;5: 283-291.

60 Von Minckwitz G: Taxanes in primary systemic treatment of breast cancer. Onkologie 2003;26 (suppl 7):21-25.

61 De Santis M, Lucchese A, de Carolis S, Ferrazani S, Caruso A: Metastatic breast cancer in pregnancy: first case of chemotherapy with docetaxel. Eur J Cancer Care (Engl) 2000;9:235-237. 
62 Gonzalez-Angulo AM, Walters RS, Carpenter RJ Jr, Ross MI, Perkins GH, Gwyn K, Theriault RL: Paclitaxel chemotherapy in a pregnant patient with bilateral breast cancer. Clin Breast Cancer 2004;5: 317-319.

63 Reynoso EE, Shepherd FA, Messner HA, Farquharson HA, Garvey MB, Baker MA: Acute leukemia during pregnancy: the Toronto Leukemia Study Group experience with long-term follow-up of children exposed in utero to chemotherapeutic agents. J Clin Oncol 1987;5:1098-1106.

64 Williams SF, Schilsky RL: Antineoplastic drugs administered during pregnancy. Semin Oncol 2000; 27:618-622.

65 Cullins SL, Pridjian G, Sutherland CM: Goldenhar's syndrome associated with tamoxifen given to the mother during gestation. JAMA 1994;271: 1905-1906.

66 Isaacs RJ, Hunter W, Clark K: Tamoxifen as systemic treatment of advanced breast cancer during pregnancy - case report and literature review. Gynecol Oncol 2001;80:405-408.

67 Clark RM, Reid J: Carcinoma of the breast in pregnancy and lactation. Int J Radiat Oncol Biol Phys 1978;4:693-698.

68 Averette HE, Mirhashemi R, Moffat FL: Pregnancy after breast carcinoma: the ultimate medical challenge. Cancer 1999;85:2301-2304.

69 Velentgas P, Daling JR, Malone KE, Weiss NS, Williams MA, Self SG, Mueller BA: Pregnancy after breast carcinoma: outcomes and influence on mortality. Cancer 1999;85:2424-2432.

70 Sankila R, Heinavaara S, Hakulinen T: Survival of breast cancer patients after subsequent term pregnancy: 'healthy mother effect'. Am J Obstet Gynecol 1994:170:818-823.

71 Falcone T, Bedaiwy MA: Fertility preservation and pregnancy outcome after malignancy. Curr Opin Obstet Gynecol 2005;17:21-26.

72 Bukovic D, Fajdic J, Hrgovic Z, Kaufmann M, Hojsak I, Stanceric T: Sexual dysfunction in breast cancer survivors. Onkologie 2005;28:29-34. 